ҚАЗАҚСТАН РЕСПУБЛИКАСЫ

ҰЛТТЫҚ ҒЫЛЫМ АКАДЕМИЯСЫНЫН

АБАЙ АТЫНДАҒЫ ҚАЗАҚ ҰЛТТЫҚ

ПЕДАГОГИКАЛЫҚ УНИВЕРСИТЕТІНІҢ

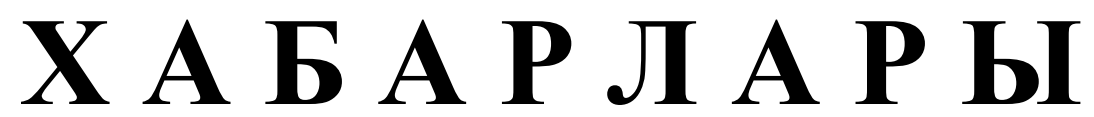

\section{ИЗВЕСТИЯ}

НАЦИОНАЛЬНОЙ АКАДЕМИИ НАУК РЕСПУБЛИКИ КАЗАХСТАН

КАЗАХСКИЙ НАЦИОНАЛЬНЫЙ

ПЕДАГОГИЧЕСКИЙ УНИВЕРСИТЕТ ИМ. АБАЯ

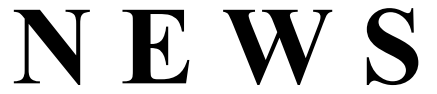

OF THE NATIONAL ACADEMY OF SCIENCES OF THE REPUBLIC OF KAZAKHSTAN

ABAY KAZAKH NATIONAL PEDAGOGICAL UNIVERSITY

ҚОҒАМДЫҚ ЖӘНЕ ГУМАНИТАРЛЫҚ ҒЫЛЫМДАР СЕРИЯСЫ

СЕРИЯ ОБЩЕСТВЕННЫХ И ГУМАНИТАРНЫХ НАУК

$\checkmark$

SERIES OF SOCIAL AND HUMAN SCIENCES

$$
5 \text { (321) }
$$

КЫРКУЙЕК - КАЗАН 2018 ж.

СЕНТЯБРЬ - ОКТЯБРЬ 2018 Г.

SEPTEMBER - OCTOBER 2018

1962 ЖЫЛДЫҢ ҚАНТАР АЙЫНАН ШЫҒА БАСТАҒАН

ИЗДАЕТСЯ С ЯНВАРЯ 1962 ГОДА

PUBLISHED SINCE JANUARY 1962

ЖЫЛЫНА 6 РЕТ ШЫҒАДЫ

ВЫХОДИТ 6 РАЗ В ГОД

PUBLISHED 6 TIMES A YEAR 
Ба с ре дактор

ҚР ҰҒА кұрметті мүшесі

Балықбаев Т.O.

Р е д а ц и я а лқ а сы:

экон. ғ. докторы, проф., ҚР ҰҒА академигі Баймұратов У.Б.; тарих ғ. докторы, проф., ҚР ҰҒА академигі Байпақов К.М.; филос. ғ.докторы, проф., ҚР ҰҒА академигі Есім Г.Е.; фил. ғ. докторы,, проф., ҚР ҰҒА академигі Қирабаев С.С.; эк. ғ. докторы, проф., ҚР ҰҒА академигі Кошанов А.К.; эк.ғ. докторы, проф., ҚР ҰҒА академигі Нәрібаев К.Н. (бас редактордың орынбасары); филос. ғ.докторы, проф., ҚР ҰҒА академигі Нысанбаев А.Н.; заң ғ. докторы, проф., ҚР ҰҒА академигі Сәбікенов С.Н.; заң ғ. докторы, проф., ҚР ҰҒА академигі Сүлейменов М.К.; эк. ғ. докторы, проф., ҚР ҰҒА академигі Сатыбалдин С.С.; тарих ғ. докторы, проф., ҚР ҰҒА академик Әбжанов Х.М.; тарих ғ. докторы, проф., ҚР ҰҒА корр. мүшесі Әбусеитова М.Х.; тарих ғ. докторы, проф., ҚР ҰҒА академик Байтанаев Б.А.; филол. ғ. докторы, проф., ҚР ҰҒА корр. мүшесі Жақып Б.А.; фил. ғ. докторы, проф., академик НАН РК Қалижанов У.К.; филол. ғ. докторы, проф., ҚР ҰҒА академик Қамзабекұлы Д.; тарих ғ. докторы, проф., ҚР ҰҒА академик Қожамжарова Д.П.; тарих ғ. докторы, проф., ҚР ҰҒА академик Койгелдиев М.К.; фил. ғ. докторы, проф., ҚР ҰҒА корр. мүшесі Кұрманбайұлы Ш.; тарих ғ. докторы, проф., ҚР ҰҒА корр. мүшесі Таймағанбетов Ж.К.; социол. ғ. докторы, проф., ҚР ҰҒА корр. мүшесі Шәукенова 3.К.; фил. ғ. докторы, проф., КР ҰҒА корр. мүшесі Дербісәлі А.; саяси. ғ. докторы, проф., Бижанов А.К., тарих ғ. докторы, проф., Кабульдинов 3.Е.; фил. ғ. докторы, проф., ҚР ҰҒА корр мүшесі Қажыбек Е.3.

\section{Р едакция ке н е с i:}

Молдова Республикасының ҰҒА академигі Белостечник Г. (Молдова); Әзірбайжан ҰҒА академигі Велиханлы Н. (Азербайджан); Тәжікстан ҰҒА академигі Назаров Т.Н. (Тәжікстан); Молдова Республикасының ҰҒА академигі Рошка А. (Молдова); Молдова Республикасының ҰҒА академигі Руснак Г. (Молдова); Әзірбайжан ҰҒА корр. мүшесі Мурадов Ш. (Әзірбайжан); Әзірбайжан ҰҒА корр. мүшесі Сафарова 3. (Әзірбайжан); э. ғ. д., проф. Василенко В.Н. (Украина); заң ғ. докт., проф. Устименко В.А. (Украина)

«Қазақстан Республикасы Ұлттық ғылым академиясының Хабарлары. Қоғамдық және гуманитарлық ғылымдар сериясы». ISSN 2224-5294

Меншіктенуші: «Қазақстан Республикасының Ұлттық ғылым академиясы» РҚБ (Алматы қ.)

Қазақстан республикасының Мәдениет пен ақпарат министрлігінің Ақпарат және мұрағат комитетінде 30.04.2010 ж. берілген № 10894-Ж мерзімдік басылым тіркеуіне қойылу туралы куәлік

Мерзімділігі: жылына 6 рет.

Тиражы: 500 дана.

Редакцияның мекенжайы: 050010, Алматы қ., Шевченко көш., 28, 219 бөл., 220, тел.: 272-13-19, 272-13-18, http://nauka-nanrk.kz. social-human.kz

(C) Қазақстан Республикасының Ұлттық ғылым академиясы, 2018

Типографияның мекенжайы: «Аруна» ЖК, Алматы қ., Муратбаева көш., 75. 
Главный редакто $p$

Почетный член НАН РК

T.O. Балыкбаев

Р е дак ци онн а я коллег и я:

докт. экон. Н., проф., академик НАН РК У.Б. Баймуратов; докт. ист. н., проф., академик НАН РК К.М. Байпаков; докт. филос. Н., проф., академик НАН РК Г.Е. Есим; докт. фил. Н., проф., академик НАН РК С.С. Кирабаев; докт. экон. Н., проф., академик НАН РК А.К. Кошанов; докт. экон. Н., проф., академик НАН РК К.Н. Нарибаев (заместитель главного редактора); докт. филос. н., проф., академик НАН РК А.Н. Нысанбаев; докт. юр. Н., проф., академик НАН РК С.Н. Сабикенов; докт. юр. н., проф., академик НАН РК М.К. Сулейменов; докт. экон. Н., проф., академик НАН РК С.С. Сатубалдин; докт. ист. н., проф., академик НАН РК Х.М. Абжанов; докт. ист. н., проф., чл.-корр. НАН РК М.Х. Абусеитова; докт. ист. н., проф., академик НАН РК Б.А. Байтанаев; докт. фил. н., проф., чл.-корр. НАН РК Б.А. Жакып; докт. фиолол. н., проф., академик НАН РК У.К. Калижанов; докт. фил. н., проф., академик НАН РК Д. Камзабекулы; докт. ист. н., проф., академик НАН РК Д.П. Кожамжарова; докт. ист. н., проф., академик НАН РК М.К. Койгельдиев; докт. филол. н., проф., чл.-корр. НАН РК Ш. Курманбайулы; докт. ист. н., проф., чл.корр. НАН РК Ж.К. Таймаганбетов; докт. социол. н., проф., чл.-корр. НАН РК З.К. Шаукенова; д. филол. н., проф., чл.-корр. НАН РК А. Дербисали; доктор политических наук, проф., Бижанов А.К.; доктор ист. наук, проф., Кабульдинов 3.Е.; доктор филол. н., проф., член-корр. НАН РК Қажыбек Е.3.

Р е дак ци онны й с ов е т

академик НАН Республики Молдова Г. Белостечник (Молдова); академик НАН Азербайджанской Республики Н. Велиханлы (Азербайджан); академик НАН Республики Таджикистан Т.Н. Назаров (Таджикистан); академик НАН Республики Молдова А. Рошка (Молдова); академик НАН Республики Молдова Г. Руснак (Молдова); чл.-корр. НАН Азербайджанской Республики Ш. Мурадов (Азербайджан), член-корр. НАН Азербайджанской Республики 3.Сафарова (Азербайджан); д. э. н., проф. В.Н. Василенко (Украина); д.ю.н., проф. В.А. Устименко (Украина)

Известия Национальной академии наук Республики Казахстан. Серия общественных и гуманитарных наук. ISSN 2224-5294

Собственник: РОО «Национальная академия наук Республики Казахстан» (г. Алматы)

Свидетельство о постановке на учет периодического печатного издания в Комитете информации и архивов

Министерства культуры и информации Республики Казахстан № 10894-Ж, выданное 30.04.2010 г.

Периодичность 6 раз в год

Тираж: 500 экземпляров

Адрес редакции: 050010, г. Алматы, ул. Шевченко, 28, ком. 219, 220, тел. 272-13-19, 272-13-18, www:nauka-nanrk.kz / social-human.kz

(C) Национальная академия наук Республики Казахстан, 2018 г.

Адрес типографии: ИП «Аруна», г. Алматы, ул. Муратбаева, 75

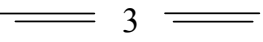


Chief Editor

\section{Honorary member of NAS RK \\ Balykbayev T.O}

Editorial board:

Doctor of economics, prof, academician of NAS RK Baimuratov U.B.; doctor of history, prof, academician of NAS RK Baipakov K.M.; doctor of philosophy, prof, academician of NAS RK Esim G.E.; doctor of philology, prof, academician of NAS RK Kirabayev S.S.; doctor of economics, prof, academician of NAS RK Koshanov A.K.; doctor of economics, prof, academician of NAS RK Naribayev K.N. (deputy editor-in-chief); doctor of philosophy, prof, academician of NAS RK Nyssanbayev A.N.; doctor of law, prof, academician of NAS RK Sabikenov S.N.; doctor of law, prof, academician of NAS RK Suleymenov M.K.; doctor of economy, prof, academician of NAS RK Satybaldin S.S.; doctor of history, prof, academician of NAS RK Abzhanov H.M; doctor of history, prof, corresponding member of NAS RK Abuseitova M.H.; doctor of history, prof, academician of NAS RK Baitanaev B.A.; doctor of philology, prof, corresponding member of NAS RK Zhakyp B.A.; doctor of philology, prof, academician of NAS RK Kalizhanov U.K.; doctor of philology, prof, academician of NAS RK Hamzabekuly D.; doctor of history, prof, academician of NAS RK Kozhamzharova D.P.; doctor of history, prof, academician of NAS RK Koigeldiev M.K.; doctor of philology, prof, corresponding member of NAS RK Kurmanbaiuly Sh.; doctor of history, prof, academician of NAS RK Taimaganbetov J.K.; doctor of sociology, prof, corresponding member of NAS RK Shaukenova Z.K.; doctor of philology, prof, corresponding member of NAS RK Derbisali A.; doctor of political science, prof Bizhanov A.K; doctor of History, prof Kabuldinov Z.E.; doctor of philology, prof, corresponding member of NAS RK Kazhybek E.Z.

\section{Editorial staff:}

Academician NAS Republic of Moldova Belostechnik.G (Moldova); Academician NAS Republic of Azerbaijan Velikhanli N. (Azerbaijan); Academician NAS Republic of Tajikistan Nazarov T.N. (Tajikistan); Academician NAS Republic of Moldova Roshka A. (Moldova) Academician NAS Republic of Moldova Rusnak G. (Moldova); Corresponding member of the NAS Republic of Azerbaijan Muradov Sh. (Azerbaijan); Corresponding member of the NAS Republic of Azerbaijan Safarova Z. (Azerbaijan); Associate professor of Economics Vasilenko V.N. (Ukraine), Associate professor of Law Ustimenko V.A. (Ukraine)

News of the National Academy of Sciences of the Republic of Kazakhstan. Series of Social and Humanities. ISSN 2224-5294

Owner: RPA "National Academy of Sciences of the Republic of Kazakhstan" (Almaty)

The certificate of registration of a periodic printed publication in the Committee of information and archives of the Ministry of culture and information of the Republic of Kazakhstan N 10894-Ж, issued 30.04.2010

Periodicity: 6 times a year

Circulation: 500 copies

Editorial address: 28, Shevchenko str., of. 219, 220, Almaty, 050010, tel. 272-13-19, 272-13-18, www:nauka-nanrk.kz / social-human.kz

(C) National Academy of Sciences of the Republic of Kazakhstan, 2018

Address of printing house: ST "Aruna", 75, Muratbayev str, Almaty 
N E W S

OF THE NATIONAL ACADEMY OF SCIENCES OF THE REPUBLIC OF KAZAKHSTAN

SERIES OF SOCIAL AND HUMAN SCIENCES

ISSN 2224-5294

https://doi.org/10.32014/2018. 2224-5294.6

Volume 5, Number 321 (2018), 39 - 43

JEL 341.4(574)

A.N. Agybayev ${ }^{1}$, A.K. Adibayeva ${ }^{2}$

${ }^{1}$ Al-Farabi Kazakh National University, Almaty, Kazakhstan;

${ }^{2}$ Kazakh Ablai Khan University of International Relations and World Languages, Almaty, Kazakhstan ka alina84@mail.ru; naylia7029@gmail.com

\title{
IMPLEMENTING MECHANISMS OF THE UN CONVENTION ON GENOCIDE IN THE CRIMINAL LEGISLATION OF THE PARTICIPATING STATES: GENERAL COMPARATIVE ANALYSIS
}

\begin{abstract}
The UN Convention on the Prevention of Genocide of 1948 is the main legal source for determining the composition of this crime. Today, the parties to the international treaty are 156 states that have implemented or are implementing conditions in the implementation of its provisions. Using comparative analysis of the criminal laws of different states, it is shown in this connection how the process of improving the effectiveness of the norms of the Convention in national legal systems is taking place. At the same time, it is confirmed that individual participating States not only formally reproduce the norms of the Convention but also purposefully implement procedures for their addition and improvement within the framework of internal jurisdictions. The result of the study is the fact that the implementation of the standard established by the Convention acquires a stable and consistent nature, and particularly for the post-Soviet republics.
\end{abstract}

Keywords: The UN Convention, genocide, implementation, criminal codes, a crime.

\section{Implications of the Convention provisions implementation for the States Parties}

The special Convention on the Prevention and Punishment of the Crime of Genocide adopted by the United Nations General Assembly on 9 December 1948 as General Assembly Resolution 260 (III) states in ArticleV that"the Contracting Parties undertake to enact, in accordance with their respective Constitutions, the necessary legislation to give effect to the provisions of the present Convention and, in particular, to provide effective penalties for persons guilty of genocide or of any of the other acts enumerated in article III." [1, p.781]. It follows from the meaning and content of the above provision that in assuming such an international obligation, a State Party to the Convention must ensure that it iseffectively implemented(enforced) throughout its territory not only by all the authoritative acts at its disposal in accordance with its constitutional and other rules and regulations not inconsistent therewith.In international law,this system of measures is referred to as "implementation" or, speaking broadly, "a mechanism of harmonizing or coordinating international and national lawsby employing recognized legal arrangements (methods)."Accordingly and in line with the norms enshrined in the Convention, a State Party shall undertake and carry out its actions aimed not as much at avoiding conflicts as atmaking national legislation that would not "conflict" with provisions of the international treaty in question.

As the current international practice shows, a more universal mechanism of implementation of this act by a State Party is to integrate its provisions into such State's national criminal law. Currently, the most common and applicable implementation methods include incorporation, reception and modification (expansion) of existing norms of criminal law in pursuance of an international treaty.

Principal mechanisms of the Convention provisions implementation in the States Parties' criminal laws

The Convention recognizes as wrongful and punishable not only genocide itself but also other acts that directly "flow" out of it,such as conspiracy to commit genocide; direct and public incitement to commit genocide; attempt to commit genocide; and complicity in genocide.

The enumerated initial forms of participation in genocide (or the so-called "inchoate crimes"), however, are not always covered by the norms of criminal laws of the States Parties. This is true, for 
example, for the majority of the post-Soviet countries such as Russia, Kazakhstan, Latvia, Moldova, Belarus, Armenia, etc. However, some of the parties to the Convention, including Azerbaijan, Austria, Bulgaria, Spain, Macedonia, Poland and the United States, considered it necessary to either partially take into account this contractual obligation or expand legal consequences of its violation. In this regard, Article 104 of the Criminal Code of Azerbaijan of 30 December 1999 contains a direct and explicit incitement to commit genocide [2, P.132]. Paragraph 2 of $\$ 321$ of the Austrian Penal Code includes such corpus delicti as conspiracy to commit genocide (it is defined as any conduct whereby(any) person agrees with another person to commit one of those acti rei specified in paragraph 1) [3, P.347].Articles 416.2 and 416.3 of the Bulgarian Criminal Code of 15 March 1968 criminalize both preparation for and explicit and direct incitement to, committing genocide [4, P.284]. In addition, according to Article 419 of the Criminal Code of the same Balkan state, culpable is any officer who, subject to distinctions in the previous articles $(416,418)$, closes his or her mind to a situation where his or her subordinates commit any of the crimes specified in Section III [5, P.284] (here it should be noted that this part of the Bulgarian Criminal Code is entitled "Liquidation of Groups of the Population (Genocide) andApartheid").

Criminal Codes of Spain, Australia, Macedonia, Poland and the United States also extend the boundaries of liability with additional elements essentialto the offence of genocide. Thus, the Spanish Penal Code of 23 November 1995, which contains the only Article 607 under Section II "Crime of Genocide", designates as another essential element a sexual assault on members of a national, ethnic, racial or religious group [6].\$3 of Article 118 of the Polish Criminal Code of 6 June 1997,likewisethe Bulgarian lawmaker, partly provides for the essential elements in the form of preparation for genocide [7, P.128]. The Macedonian Criminal Code of 23 July 1996 sees creation of a group with the purpose of committing genocide as a qualifying element [8]. And finally, the US Federal Criminal Code of4 May 1962 stipulates in $\$ 1091$ that the crime of genocide can be committed both during peacetime and wartime [9], and also contains $\$ 1093$ "Definitions"where the notions of "children", "ethnic group", "national group", "racial group", "religious group", "members", etc. are defined [10].

Recently, "there is a clear tendency towards a more extensive interpretation of the object of genocide"[11] in national criminal laws,"which can be caused by various reasons in different states"[12].For instance, this way was chosen by lawmakers in such countries as Latvia, Belarus, France, Poland, Lithuania,says R.C. Clarke in his paper entitled "Together Again? Customary Law and Control over the Crime" (2015), [13,P.487],as well as Estonia. Thus, Article 71 of the Latvian Criminal Code of 8 July 1998 includes in the object of genocide not only "national, ethnic, racial or religious groups" but also any "social group, a group of people of certain common beliefs" [14]. According to $§ 1$ of Article 118 of the Polish Criminal Code, two more new categories are recognized as genocide victims: "political groups and groups with a certain worldview" [15].The Lithuanian Criminal Code of26 September 2000 expands the orbit of genocide victims to also include "social and political groups" [16,C.97].Article 211-1 of the French Criminal Code which entered into force on 1 March 1994 (as subsequently amended) [17, P.165] and Article 127 of the BelarussianCriminal Code of9 July 1999 [18] add"groups identified by any other arbitrary criterion"to the objects of genocide, save for those groups of people specified in Article II of the 1948 Convention. While the Estonian Criminal Code of 1 September 2002, according to some experts, contains a more "unique definition of genocide victims as compared to legislation of other states"[19] being a "group opposing an occupation regime, or another social group" [20]. It is also noteworthy that the old version FRG Criminal Code ( $\$ 220$ a of Section 16 of the Special Part, "Crimes Against Life"),prior to adopting the Act to Introduce theCode of Crimes against International Law, defined the object of genocide as a "certain distinct group"(in another similar version - a "group (community) distinguished by its traditions" [21].

In agreement with the position of N.V. Moshenskaya, for our own part we believe that genocide always means a deliberate crime aimed at exterminating a stable group of people [22].Besides, we also believe that new notions that expand the scope of the genocide object cover such acti rei as enumerated in the prevailing international law provisions and, namely, in the Rome Statute of17 July 1998. While establishing generallytrue meaning of the concept of genocide according to Article 211-1 of the French Criminal Code which also extends the scope of the object of crime by including thereto a "...group characterized by any other arbitrary criterion,"V.M. Vartanyan nevertheless admits that there is a good sense to this approach [23,C.62]. In support of his conclusion, he writes: for example, "some community of women starts committing actions aimed at liquidation of male population" [24, P.62]. "From the 
international law perspective, such actions cannot be called a genocide of the male population, although they objectively areone" [25, P.62] and "in this case, the French Criminal Code covers such actions as essential elements of genocide"[26,C.62].

However, international practice also knows such a specific way of implementing the 1948 Convention as development, adoption and approval at the highest legislative level of an entire regulatory act. Here, the abovementioned German Act to Introduce theCode of Crimes against International Law of 26 June 2002 is no doubt a vivid example (another frequent name is the International Criminal Code; in GermanVölkerstrafgesetzbuch (VStGB). This law, enacted by the German Bundestag, has "enriched" primarily the system of sources for the German criminal law and thereby strengthened the so-called "supplementary penal provisions" (Nebenstrafrecht) of the country and, secondly, in $\S 6$, formulated the crime of genocide which now matches the definition provided for in Article II of the 1948 Convention as well as in Article 6 of the Rome Statute of the International Criminal Court. Accordingly, with the adoption of the new Criminal Code, \$220a was completely deleted from the old version of the Federal Republic of Germany criminal law which was introduced into its system by the Act of 9 August 1954 and became effective on 22 February 1955. It should also be noted that $\$ 6$ which deals with genocide (Völkermord), along with $\S 7$ (crimes against humanity -Verbrechen gegen die Menschlichkeit), for the first time formed a new section in the special part of the International Criminal Code of this state."The German Criminal Code had no"separate section as such prior to its adoption [27, P.33], which speaks for a completely different quality of implementation of the norms of the 1948 UN Convention in the country's national legislation [28,C.33].

Similar criminal laws under which the States being parties to the 1948 Convention implemented their obligations were also adopted in Belgium (simultaneously withit there operates in this Western European country the Criminal Code of 8 June 1867 with numerous amendments reflecting the position of the legislator inXX century and beginning of XXI century) and Canada (in 2000, the Crimes Against Humanity and War Crimes Act was approved and enacted in this North American state.

It is important to emphasize that "responsibility for genocide is not limited to mere criminal one" [29]. But at the same time, Article IV of the 1948 Convention uses the term "punishment" which, apparently, is interpreted by international experts as an element of exclusively criminal responsibility"[30]. As noted by D.A. Dam-de Jong, after adoption of the Convention, the "states went along different paths in addressing the issue of punishment for the crime of genocide"[31,P.237].

As such, it is imposed and implemented in the form of various sanctions by national courts. For example, in the criminal codes of Austria (paragraph 1 of §321), France (Article 211-1) and Germany (§6 of the ICC) the basic constituent parts of genocide include an absolutely definite coercive measure that entails adverse consequences for the offender - life imprisonment ("life sentence" in the French version). However, most of the States Parties to the Convention use an alternative sanction, i.e.custodial sentence besides life imprisonment. National criminal codes provide for different terms of imprisonment: 8 to 15 years (Article 61 of the Estonian Criminal Code; not less than 10 years (Article 264 of the Swiss Criminal Code); 10 to 15 years (Articles 103, 104 of Azerbaijan Criminal Code); 12 to 15 years (Article 393 of the Armenian Criminal Code); 10 to 20 years (Articles 416, 417 of the Bulgarian Criminal Code); 3 to 20 years (Article 71 of the Latvian Criminal Code); 15 to 20 years (Article 607 of the Spanish Criminal Code); 12 to 25 years (Article 118 of the Polish Criminal Code); 16 to 25 years (Article 135 of the Moldavian Criminal Code).In some countries, the sanction provides for possibility of using death penalty for the commission of genocide (Article 127 of the Belarussian Criminal Code). In Kazakhstan, this capital punishment is imposed in case of genocide in wartime (Article 168 of the Criminal Code). In paragraph 2 of $\S 6$ of the FRG ICC, there is a norm which "contains no qualified type of genocide but establishes criminal liability for a less serious case of genocide, i.e. a norm containing the rules for determining the amount of penalty (Strafzumessungsregeln)"[32, P.34-35] Paragraph 2 itself reads:"In less serious cases referred to under subsection (1),numbers 2 to 5 , the punishment shall beimprisonment for not less than five years"[33]. In the opinion of A.V. Serebrennikova, "In practice, this rule should be applied primarily to genocide which resulted in no deaths"[34, P.35].

Whileanalysing modern criminal laws of states (mainly European and post-Soviet states), it can be noted that "salient features of national legal systems translated into the ways of implementing the norms of international law on genocide, reflecting their belonging to a particular legal family, national legal traditions, the level of public sense of justice, individualities of legislative process" [35].In this regard, L. Kazyrytski particularly emphasizes that Roman law is the basis of legal systems of most of the above states belonging to the Romano-Germanic legal family [36, P.18]. In turn, it recognizes normative legal 
act as the main source of law[37,P.18]. However, in this context, we particularly support the position of the Russian scholar N.A. Shulepov, according to whom the experience of implementing the norms on genocide by various states is not only of scientific but also of practical interest, since it can be used by the national legislator in improving the criminal code as to criminalization of international crimes [38]. This is fully relevant to the applicable laws of many states and, in particular, post-Sovietones.

\section{Conclusion}

In a strictly legal context, it cannot be overlooked that, while obligingthe States Parties to provide effective measures for implementation, the Convention also affords them open opportunities for "manoeuvre." This means that each State Party can resort to those measures as are conditioned by its autocratic discretion (compulsion) depending on one or another factual circumstance.The above examples and their simultaneous comparative analysis show that wordings of criminal laws either generally match provisions of the Convention or include elements of the crime of genocide in criminal codes without any firmly established form and not only within single article, or not as much formally perceive direct regulations approved in accordance with internal constitutional procedure of an international treaty as they expand their functional content by fixing not one but several instances ofcorpus delicti of genocide.However, such actions - recognition and development of various and, it should be emphasized, not contradicting and not excluding each other, legal forms of implementation, as well as their harmonization - in each case are underpinned by political will of the StateParty.

\section{REFERENCES}

[1] Konventsiya o preduprezhdenii prestupleniya genotsida I nakazanii za nego ot 9 dekabrya 1948 goda // Prava cheloveka. Sbornik mezhdunarodnykh dogovorov. Tom I (chast vtoraya). - OON: Nyu-Iork i Zheneva, 1994. - $1023 \mathrm{~s}$.

[2] Ugolovnyy kodeks Azerbaidzhanskoi Respubliki ot 30 dekabrya 1999 goda. - Sankt-Peterburg: Izdatelstvo "Yuridicheskiy tsentr Press", 2001. - 2325s.

[3] Ugolovnyy kodeks Avstrii ot 29 yanvarya 1974 goda. - Sankt-Peterburg: Izdatelstvo „Yuridicheskiy tsentr Press", 2004. - 352s.

[4] Ugolovnyy kodeks Respubliki Bolgariya ot 15 marta 1968 goda. - Sankt-Peterburg: Izdatelstvo "Yuridicheskiy tsentr Press", 2001. - 289s.

[5] Ibid.

[6] Ugolovnyy kodeks Ispanii ot 23 noyabrya 1995 goda - M.: Zertsalo, 1998. - 218s.

[7] Ugolovnyy kodeks Respubliki Polsha ot 6 iyunya 1997 goda. - Minsk: Izdatelstvo „Tesei”, 1998. - 127 s.

[8] Ugolovnyy kodeks Makedonii ot 23 iyulya 1996 goda URL: www.m/rc.org.mk/law/Criminal/Code.htm.

[9] Criminal Code of USA, May 4, 1962 // http://www.law.cornell.edu /uscode / text/ 18/ part - I.

[10] Ibid.

[11] Moshenskaya N.V. Genosid - istoricheskaya i pravovaya kharakteristika ponyatiya// Advokatskaya praktika. - 2005. №3.- S.30-35.

[12] Ibid.

[13] Clarke R.C. Together Again? Customary Law and Control over the Crime. Criminal Law Forum, 2015. 26(3). - Pp. 457-495. (In Eng.)

[14] Ugolovnyy kodeks Latviyskoi Respubliki ot 8 iyulya 1998 goda. - Sankt-Peterburg: Izdatelstvo „Yurid. tsentr press", 2001. $-2325 \mathrm{~s}$

[15] Ugolovnyy kodeks Respubliki Polsha ot 6 iyunya 1997 goda. - Minsk: Tesei, 1998. - 127 s.

[16] Ugolovnyy kodeks Litovskoi Respubliki ot 26 sentyabrya 2000 goda. - (148s.).

[17] Ugolovnyy kodeks Frantsii ot 1 yanvarya 1992g. Sankt-Peterburg: Izdatelstvo „Yuridicheskiy tsentr Press". 2002. 648s.

[18] Ugolovnyy kodeks Respubliki Belorus ot 9 iyulya 1999 g. // http: //www.base.spinform.ru

[19] Pankratova E.D. Ugolovno-pravovaya harakteristika genosida. diss.kand.yurid.nauk. - M.: MGYUA imeni O.E.Kutafina, 2010. - 200s.

[20] Ugolovnyy kodeks Estonskoi Respubliki. S izmeneniyami i dopolneniyami na 1 avgusta 2001 g. - Yurid. tsentr Press, 2001. $-262 \mathrm{~s}$.

[21] Ugolovnyy kodeks Federativnoi Respubliki Germanya ot 26 iyunya 2002 goda// P.V. Golovnenkov Ugolovnoe ulozhenie (Ugolovnyy kodeks) Federativnoi Respubliki Germanya: nauchno-prakticheskiy kommentariy i perevod teksta zakona. 2-e izdanie. Izdatelstvo "Prospekt" 2012. - 312s.

[22] Moshenskaya N.V. Ukaz. soch.

[23] Vartanyan V.M. Ugolovnaya otvetstvennost za genosid. diss.kand.yurid. nauk. - Stavropol; Stavropolskii gosudarstvennii universitet, 2000. - $166 \mathrm{~s}$.

[24] Ibid.

[25] Ibid.

[26] Ibid.

[27] Serebrennikova A.V. Implementatsiya port mezhdunarodnogo ugolovnogo prava o genoside vo vnutrennee zakonodatelstvo Rossiyskoi Federatsii I Germanii // Yuridicheskie zapiski, 2014. №1. - S.31-35.

[28] Ibid.

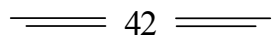


[29] Moshenskaya N.V. Ukaz. soch.

[30] Ibid.

[31] Dam-de Jong D.A. The Role of Informal Normative Processes in Improving Governance over Natural Resources Conflict-Torn States // Hague Journal on the Rule of Law, №7 (2), 2015. - Pp. 219-241.

[32] Serebrennikova A.V. Ukaz.soch. - S.31-35.

[33] Völkerstrafgesetzbuch (vVStGB) от 26. Juni 2002 (B GBI.IS. 2254) // Ein Service des Bundesministeriums der Justiz und für Verbraucherscutz in Zusam - menarbeit mit der juris Gmbn // www.juris.de

[34] Serebrennikova A.V. Ukaz.soch. - S.31-35.

[35] Shulepov N.A. Implementatsiya norm mezhdunarodnogo prava o genotside $v$ ugolovnom zakonodatelstve zarubezhnykh stran // voen prav. ru/docs/20/-2261. doc (Data poseshcheniya: 5 maya 2016g.)

[36] Kazyrytski L. Latvian SS-Legion: Past and Present. Some Issues Regarding the Modern Glorification of Nazism //Criminal Law Forum. 2016. - Pp.1-25.

[37] Ibid.

[38] Shulepov N.A. Ukaz.soch.

\title{
А.Н. Ағыбаев ${ }^{1}$, А.К. Адибаева ${ }^{2}$
}

${ }^{1}$ Әл-Фараби атындағы ҚазҰУ, Кеден, қаржы және экологиялық құқық кафедрасы, Алматы қаласы, ҚР

${ }^{2}$ Абылай хан атындағы ҚазХҚ және ӘТУ, Халықаралық құқық кафедрасы, Алматы қаласы, ҚР

\section{ГЕНОЦИД ТУРАЛЫ БҰҰ КОНВЕНЦИЯСЫНЫН ҚАТЫСУШЫ МЕМЛЕКЕТТЕРДІН ҚЫЛМЫСТЫК ЗАННАМАЛАРЫНДАҒЫ ИМПЛЕМЕНТАЦИЯЛЫК ТЕТІКТЕРІ: ЖАЛПЫ САЛЫСТЫРМАЛЫ ТАЛДАУ}

\begin{abstract}
Аннотация. БҰҰ геноцидке қарсы іс-қимылдары туралы 1948 жылғы Конвенциясы осы аталған қылмыс құрамын анықтайтын басты заңи қайнар көзі болып табылады. Бүгінде бұл халықаралық шарттың қатысушылары қатарында 156 мемлекет бар. Олардың әрқайсысы өз кезегінде құжаттың ережелерін жүзеге асырып үлгерген немесе орындау үстінде. Осы орайда әртүрлі мемлекеттердің қылмыстық заңдарын салыстырмалы талдау әдісі арқылы қарастыра отырып Конвенция нормаларының тиімділігін ұлттық құқықтық жүйелер аясында қалай арттырылып жатқаны көрсетілген. Сонымен қатар мақалада жеке қатысушы мемлекеттердің Конвенция нормаларын формалды түрде қабылдап қана қоймай, оларды тиісінше өзіндік ішкі юрисдикциялар шеңберінде арнайы мақсат тұтып, толықтырып және жетілдіріп жатқан процедуралары дәлелденеді. Жүргізілген зерттеудің нәтижесінде Конвенцияда бекітілген стандарттың енгізілуі тұрақты және жүйелі сипатқа ие болып отырған фактісі анықталған. Әсіресе, бұл үрдіс посткеңестік мемлекеттерге тән.
\end{abstract}

Түйін сөздер:БҰҰ Конвенциясы, геноцид, имплементация, қылмыстық кодекстар, қылмыс.

УДК $341.4(574)$

\section{А.Н. Агыбаев ${ }^{1}$, А.К. Адибаева}

'КазНУ имени Аль-Фараби, кафедра таможенного, финансового и экологического права, г.Алматы, РК; ${ }^{2}$ КазУМО и МЯ имени Абылай Хана, кафедра международного права и юриспруденции, г.Алматы, РК

\section{ИМПЛЕМЕНТАЦИОННЫЕ МЕХАНИЗМЫ КОНВЕНЦИИ ООН О ГЕНОЦИДЕ В УГОЛОВНЫХ ЗАКОНОДАТЕЛЬСТВАХ ГОСУДАРСТВ-УЧАСТНИКОВ: ОБЩИЙ СРАВНИТЕЛЬНЫЙ АНАЛИЗ}

Аннотация. Конвенция ООН о противодействии геноциду 1948 года является главным юридическим источником для определения состава данного преступления. Сегодня участниками международного договора являются 156 государств, которые осуществили либо осуществляют условия во исполнение его положений. С использованием сравнительного анализа уголовных законов разных государств в этой связи показано, как происходит процесс повышения эффективности норм Конвенции в национальных юридических системах. Одновременно подтверждается, что отдельные государства-участники не только формально воспроизводят нормы Конвенции, но и целенаправленно реализуют процедуры по их дополнению и совершенствованию в рамках внутренних юрисдикций. Результатом проведенного исследования является тот факт, что внедрение установленного Конвенцией стандарта приобретает устойчивый и последовательный характер, и в частности, для постсоветских республик.

Ключевые слова: Конвенция ООН, геноцид, имплементация, уголовные кодексы, преступление.

\section{Information about authors:}

Agybayev A.N. - Doctor of juridical sciences, professor, chair of customs, financial and environmental law, Al-Farabi Kazakh National University, Almaty, Kazakhstan;

Adybayeva A.K. - Ph.D Candidate, Kazakh National University named after Al Farabi, Lecturer of the International Law, Kazakh Ablai Khan University of International Relations and World Languages, Almaty, Kazakhstan, https://orcid.org/0000$\underline{0002-7463-9435}$ 


\section{МАЗМҰНЫ}

Алтыбаева С.М., Савындыков Е.С. Көркем мәтін құрылымындағы мифопоэтикалық модельдеу және мәдени код...... 5 Сембиева Л.М., Мажитов Д.М., Карпиикая М.Е., Хамитова Д.М. Экономиканы жаңғырту жағдайындағы ЕАЭО елдерінің монетарлық жүесінін өзгеруі .....

Құлсариева А.Т., Султанова М.Э., Шайгозова Ж.Н. Фольклор және сәйкестілік: Қазақстанның қазіргі заманғы

мәдениетіндегі тарих, жады және аңыз шығармашылығы ........................................................................................... 19

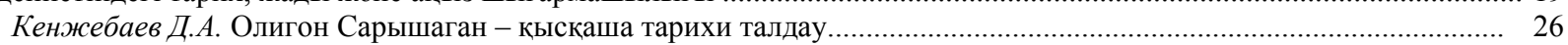

АбдулинаГ.А., БазарбаевА.Г. Ұйымдардағы адам ресурстарын басқарудың заманауи тұжырымдамалары................ 33

Авыбаев А.Н., Адибаева А.К. Геноцид туралы БҰҰ Конвенциясының қатысушы мемлекеттердің қылмыстық

заңнамаларындағы имплементациялық тетіктері: жалпы салыстырмалы талдау............................................................ 39

Ахметжанов Б., Тәжібекова К.Б., Шаметова А.А. Қазақстан көлік өнеркәсіптің дамуын талдау............................. 44

Аюпова 3.К., Құсайынов Д.Ө. Тәуелсіздік жағдайындағы қазақстан республикасының конституциялық-құқықтық

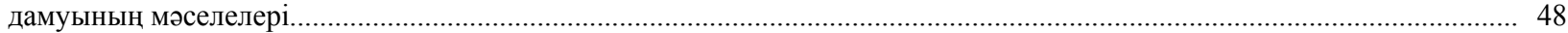

Нурпеисова А.А., Рей И.Ю., Бижанов Д.Т., Тлеужанова Д.А. Инновациялық өндірісді жасаудың процесін

бақылауының негізгі элементтері

Гиздатов Г.Г. Қазақстандық дискурсының құрылымы психолингвистиякалық зерттеу .

Ищанова Р.К. Мемлекеттік шығындарды басқару - мемлекеттің қаржылық тұрақтылығын қамтамасыз ету.............. 64

Мадышева А.М. Бикенова А.С., Елеусиз Л.Т. Білім саласындағы туристік қызметтер............................................. 68

Ескалиева А. Ж., Баймуханова М.Т., Ахмурзина Д.О. Әлеуметтік сала адам капиталының сапасын қолдаудың

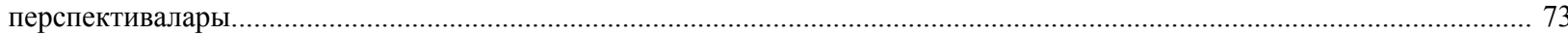

Мархаева Б.А., Козбахова Д.Л. Жауапкершілік орталық және трансферттік баға белгілеу............................................ 79

Сабирова Р.К., Утепкалиева К.М., Кабаков С.Б. Қазақстандағы ауыл шаруашылығы экономикасының

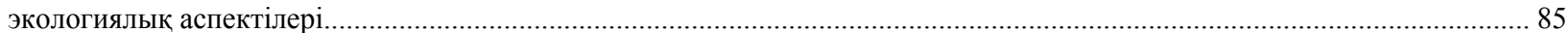

Тлесова Э., Хойч А., Кураш Н. Қазақстан республикасының ғылыми инновациялық потенциясы және оның

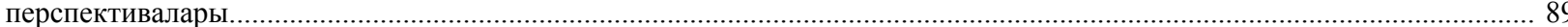

Хамитхан Н. Қазақстандағы банктік қызметтердің сапасын жақсарту жағдайында банкаралык басекелестік............ 95

Шалдарбеков Қ.Б., Муханова Г.С., Нурмухамбетова 3.С. Аймақтарды дамыту бағдарламаларын жүзеге асырудағы жобалық басқаруды қолданудың шетелдік тәжірибесі

КаратаеваА.М., Бердиярова Ж.С. Мемлекеттік қызметшінің әдептік мәдениеті және құқықтық мәдениеті

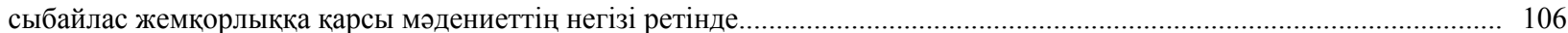

Алдабергенова А.А. Абсурд әдебиетін аударудың лингвомәдени аспектілері ................................................... 113

Стукач В. Ф., Байдалинова А. С., Сандыбаева Б. А. Қазақстанның қаржылық қауіпсіздігі......................................... 119

Баймаханова Д.М., Оспанова Д.А. Конституциялық-құқықтық сана - конституционализмнің маңызды

компоненті ретінде және оның адам құқықтары мәселелерін шешудегі рөлі................................................................. 126

Имангожина 3.А. Сланцевая революция: глобальный тренд на мировом энергетическом рынке............................. 137

Ракаева А.Н., Жуматаева Б.А., Успамбаева М.К., Доскалиева Б.Б. Экологиялық есеп қазақстандағы кәсіпорын экономикасының даму кезеңі ретінде

Нуржанова Г.И. Экономиканың аграрлық секторындағы еңбек әлеуетіне демографиялық фактордың әсері............ 147

Оспанова Д.А., Баймаханова Д.М. Қазақстан Республикасының кибер кеңістігін дамыту жағдайында мемлекеттік қызметтерді цифрландыруда әкімшілік-құқықтық қамтамасыз ету ................................................................................... 152

Pblсnекова М.О., Тлесова Э.Б., Хаитбаева Ф.К. Қазақстандағы тұрғын үй-коммуналдық шаруашылық қызметін

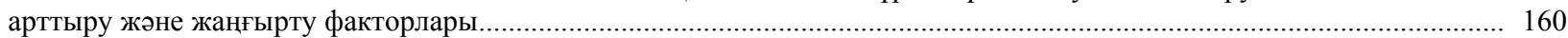

Султанова Г. Т. Аграрлық сектордың экспорттық әлеуетін дамытуға бағытталған үрдістер мен басымдықтар........ 166 


\section{СОДЕРЖАНИЕ}

Алтыбаева С.М., Сагындыков Е.С. Культурный код и мифопоэтическое моделирование в структуре художественного текста

Сембиева Л.М., Мажитов Д.М., Карпиикая М.Е., Хамитова Д.М. Трансформация монетарной системы стран

ЕАЭС в условиях модернизации экономики

Кулсариева А.Т., Султанова М.Э., Шайгозова Ж.Н. Фольклор и идентичность: история, память и мифотворчество

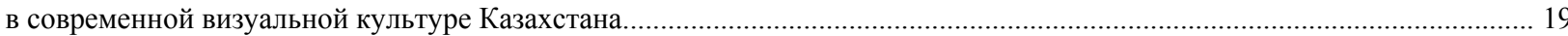

Кенжебаев Д.А. Полигон Сарышаган - краткий исторический анализ................................................................ 26

Абдулина Г.А., БазарбаевА.Г. Современные концепции управления человеческми ресурсами в организациях............ 33

Агыбаев А.Н., Адибаева А.К. Имплементационные механизмы Конвенции ООН о геноциде в уголовных

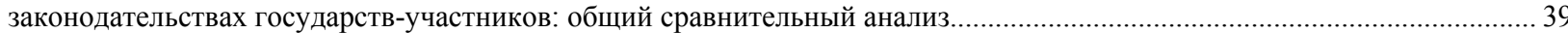

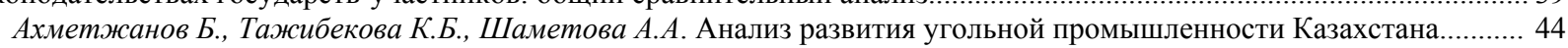

Аюпова 3.К., Кусаинов Д.У.Проблемы конституционно-правового развития республики Казахстан в условиях суверенитета ......

Нурпеисова А.А., Рей И.Ю., Бижанов Д.Т., Тлеужанова Д.А. Основные элементы управления процессом создания инновационной продукции ....

Гиздатов Г.Г. Психолингвистическое исследование концептов казахстанского дискурса......

Ищанова Р.К. Управление государственными расходами - как обеспечение финансовой устойчивости государства. 64

Мадышева А.М. Бикенова А.С., Елеусиз Л.Т. Туристские услуги в сфере образования................................................. 68

Ескалиева А. Ж., Баймуханова М.Т., Ахмурзина Д.О. Перспективы усиления качества человеческого капитала

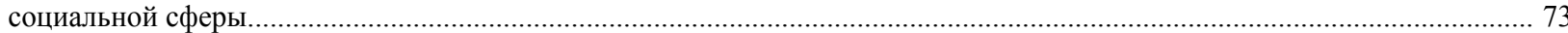

Мархаева Б.А., Козбахова Д.Л. Центр ответственности и трансфертное ценообразование....................................... 79

Сабирова Р.К., Утепкалиева К.М., Кабаков С.Б. Экологические аспекты экономики сельского хозяйства

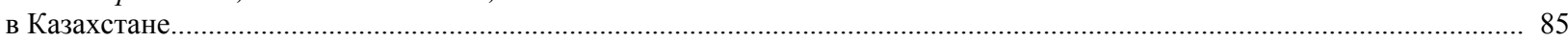

Тлесова Э., Хойч А., Кураш Н. Научно-инновационный потенциал республики Казкастан и его перспективы............ 89

Хамитхан Н. Межбанковская конкуренция в условиях повышения качества банковских услуг в Казахстане..............95

Шалдарбеков К.Б., Муханова Г.С., Нурмухамбетова З.С. Зарубежный опыт применения проектного управления

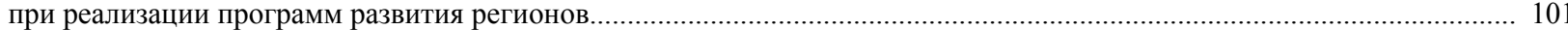

Каратаева А.М., Бердиярова Ж.С. Этическая культура и правовая культура государственных служащих

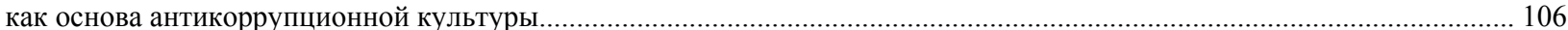

Алдабергенова А.А. Лингвокультурологические аспекты перевода литературы абсурда........................................... 113

Стукач В. Ф., Байдалинова А. С., Сандыбаева Б. А. Казахстанская финансовая безопасность................................... 119

Баймаханова Д.М., Оспанова Д.А. Конституционно-правовое сознание как важный компонент конституционализма

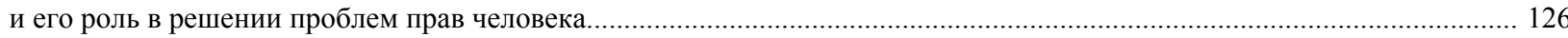

Имангожина 3.А. Сланцевая революция: глобальный тренд на мировом энергетическом рынке............................ 137

Ракаева А.Н., Жуматаева Б.А., Успамбаева М.К., Доскалиева Б.Б. Экологический учет как ступень развития

экономики предприятия в Казахстане............................................................................................

Нуржанова Г.И. Влияние демографического фактора на трудовой потенциал аграрного сектора экономики............ 147

Оспанова Д.А., Баймаханова Д.М. Административно-правовое обеспечение цифровизации государственных услуг в условиях развития кибер пронстранства республики Казахстан......

Рыспекова М.О., Тлесова Э.Б., Хаитбаева Ф.К. Факторы инновационной модернизации и совершенствования деятельности жилищно-коммунального хозяйства в Казахстане

Султанова Г. Т. Тенденции и приоритеты развития экспортного потенциала аграрного сектора... 


\section{CONTENTS}

Altybayeva S.M., Sagyndykov E.S. Cultural code and myth poetic modeling in the structure of the artistic text..................... 5 Sembiyeva L.M., Mazhitov D.M., Karpitskaya M.E., Khamitova D.M. Transformation of the monetary system of the eurasian economic UNION countries in the conditions of modernization of the economy......

Kulsarieva A.T., Sultanova M.E., Shaigozova Zh.N. Folklore and identity: history, memory and myth-making in the modern

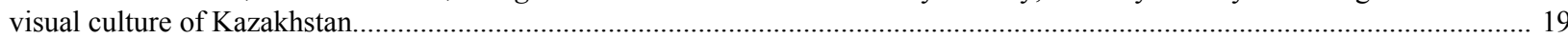

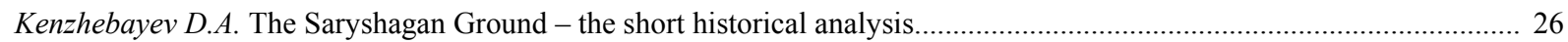

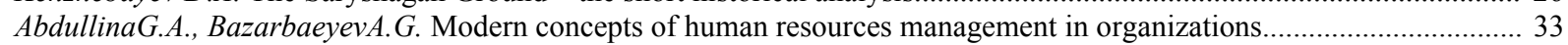

Agybayev A.N., Adibayeva A.K. Implementing mechanisms of the UN Convention on genocide in the criminal legislation

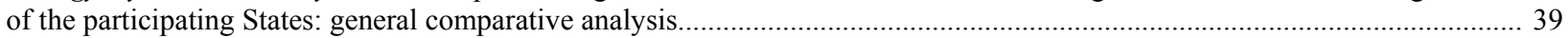

Akhmetzhanov B., Tazhibekova K.B, Shametova A.A. Analysis of development of the coal industry of Kazakhstan.............. 44 Ayupova Z.K., Kussainov D.U. Problems of constitutional and legal development of the republic of kazakhstan in the conditions of sovereignty......

Nurpeisova A.A., Rey I.Yu., Bizhanov D.T., Tleuzhanova D.A. Main elements of managing the process of creating innovation production.

Gizdatov G.G. Psycholinguistic study of the concepts of Kazakhstar

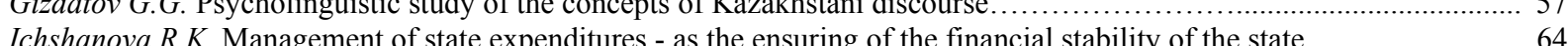

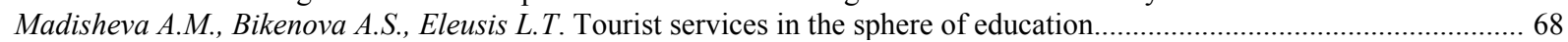

Eskalieva A. Zh., Baymukhanova M.T., Ahmurzina D.O. Perspectives of strengthening the quality of the human capital

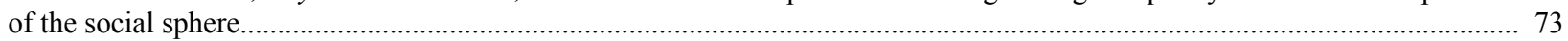

Markhayeva B.A., Kozbakhova D.L. A responsibility center and transfer pricing ................................................. 79

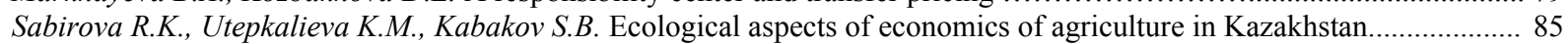

Tlessova E., Khoich A., Kurash N. Scientific innovation potential of the republic of Kazkahstan and its perspectives........ 89

Hamitkhan $N$. Interbank competition in conditions of improving the quality of banking services in Kazakhstan.................. 95

Shaldarbekov K., Mukhanova G., Nurmukhambetova Z. International practices in project management in implementing

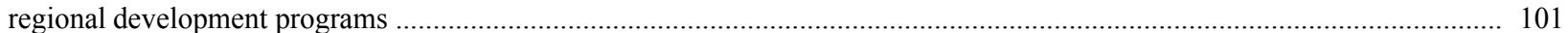

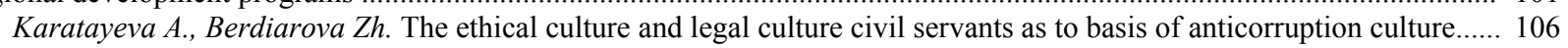

Aldabergenova A.A. Linguocultural aspects of translation of absurd literature.............................................................. 113

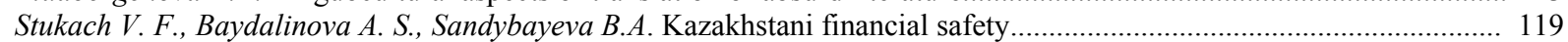

Baimakhanova D.M., Ospanova D.A. Constitutional and legal consciousness as an important component of constitutionalism

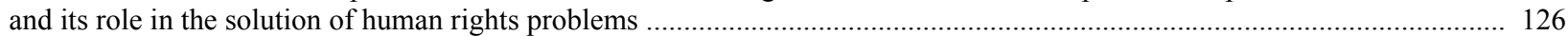

Imangozhina Z.A. Shale gas revolution: global trend in the world energy market..................................................... 137

Rakaeva A.N., Zhumataeva B.A., Uspanbayeva M.K., B.B.Doskalieva. Level of ecological report development in the economic of Kazakhstan's companies.

Nurzhanova G.I. Impact of demographic factors on labor potential of economy's agricultural sector

Ospanova D.A., Baimakhanova D.M. Administrative and legal support of digitalization of public services in the context of the development of cyber space in the republic of Kazakhstan....

Ryspekova M.O., Tlessova E.B., Khaitbayeva F. Factors of innovative modernization and improvement of activity

of housing and communal services in Kazakhstan.

Sultanova G. T. Trends and priorities for the development of export potential of the agrarian sector. 


\title{
PUBLICATION ETHICS AND PUBLICATION MALPRACTICE IN THE JOURNALS OF THE NATIONAL ACADEMY OF SCIENCES OF THE REPUBLIC OF KAZAKHSTAN
}

For information on Ethics in publishing and Ethical guidelines for journal publication see http://www.elsevier.com/publishingethics and http://www.elsevier.com/journal-authors/ethics.

Submission of an article to the National Academy of Sciences of the Republic of Kazakhstan implies that the work described has not been published previously (except in the form of an abstract or as part of a published lecture or academic thesis or as an electronic preprint, see http://www.elsevier.com/postingpolicy), that it is not under consideration for publication elsewhere, that its publication is approved by all authors and tacitly or explicitly by the responsible authorities where the work was carried out, and that, if accepted, it will not be published elsewhere in the same form, in English or in any other language, including electronically without the written consent of the copyrightholder. In particular, translations into English of papers already published in another language are not accepted.

No other forms of scientific misconduct are allowed, such as plagiarism, falsification, fraudulent data, incorrect interpretation of other works, incorrect citations, etc. The National Academy of Sciences of the Republic of Kazakhstan follows the Code of Conduct of the Committee on Publication Ethics (COPE), and follows the COPE Flowcharts for Resolving Cases of Suspected Misconduct (http://publicationethics.org/files/u2/New Code.pdf). To verify originality, your article may be checked by the originality detection service Cross Check http://www.elsevier.com/editors/plagdetect.

The authors are obliged to participate in peer review process and be ready to provide corrections, clarifications, retractions and apologies when needed. All authors of a paper should have significantly contributed to the research.

The reviewers should provide objective judgments and should point out relevant published works which are not yet cited. Reviewed articles should be treated confidentially. The reviewers will be chosen in such a way that there is no conflict of interests with respect to the research, the authors and/or the research funders.

The editors have complete responsibility and authority to reject or accept a paper, and they will only accept a paper when reasonably certain. They will preserve anonymity of reviewers and promote publication of corrections, clarifications, retractions and apologies when needed. The acceptance of a paper automatically implies the copyright transfer to the National Academy of sciences of the Republic of Kazakhstan.

The Editorial Board of the National Academy of sciences of the Republic of Kazakhstan will monitor and safeguard publishing ethics.

Правила оформления статьи для публикации в журнале смотреть на сайте:

$$
\begin{gathered}
\text { www:nauka-nanrk.kz } \\
\text { social-human.kz }
\end{gathered}
$$

\author{
Редакторы М.С. Ахметова, Т.А. Апендиев, Д.С. Аленов \\ Верстка на компьютере А.М. Кульгинбаевой \\ Подписано в печать 10.10.2018 \\ Формат 60x881/8. Бумага офсетная. Печать - ризограф. \\ 11,6 п.л. Тираж 500. Заказ 5.
}

